\title{
Use of fatty acid profiles to monitor the escape history of farmed Atlantic salmon
}

\author{
Ove T. Skilbrei ${ }^{1, *}$, Eirik Normann ${ }^{2}$, Sonnich Meier ${ }^{1}$, Rolf Erik Olsen $^{1,3}$ \\ ${ }^{1}$ Institute of Marine Research, PO Box 1870 Nordnes, 5817 Bergen, Norway \\ ${ }^{2}$ Laboratory for fresh water ecology (LFI), Uni Research Environment, Uni Research, 5008 Bergen, Norway \\ ${ }^{3}$ Department of Biology, Norwegian University of Science and Technology, 7489 Trondheim, Norway
}

\begin{abstract}
Farmed Atlantic salmon can escape from fish farms at various stages of their life, from juveniles to large mature fish. Escapees that enter rivers to spawn pose a threat to the genetic integrity of wild populations. Knowledge about the timing of these escapes can provide important information for wildlife management and the aquaculture industry, enabling them to prevent or mitigate the negative impacts of escapees. Farmed salmon food has a high content of terrestrial lipids; thus, we used fatty acid (FA) profiling to monitor the escape history of farmed salmon. Escaped salmon captured in rivers $(\mathrm{n}=251)$ presented a wide range of FA profiles that we used to classify the fish as (1) early-escaped wild-like fish that were assumed to have escaped at smolt or early post-smolt stage $(24 \%),(2)$ recently escaped fish with high levels of FAs typically found in commercial salmon food (61\%) and (3) intermediate escapees whose FA profiles lay between those 2 groups (15\%). To estimate the size at escape of the intermediate escapees, we performed a feeding experiment that monitored the development of FA profiles after a shift in diet from terrestrial to marine lipids. Most intermediate escapees appeared to have escaped when they were $<3 \mathrm{~kg}$, and ranged from 3 to $11 \mathrm{~kg}$ when recaptured in rivers. We conclude that FA profiling is a promising tool to monitor escape histories, and that the proportion of post-smolt escapees in this study was high compared to official escape statistics which include very few reports of young fish escaping.
\end{abstract}

KEY WORDS: Escaped farmed salmon - Fatty acids - Triacylglycerols · Lipids · Aquaculture · Environmental impacts

\section{INTRODUCTION}

Atlantic salmon Salmo salar L. farming is a growing aquaculture industry, with a total global production of 1.426 million $t$ in 2010 (FAO 2012). Escapes of farmed fish have raised concerns regarding their potential impacts on the environment. Escaped salmonids may spread diseases (Johansen et al. 2011) and parasites such as salmon lice (Heuch \& Mo 2001, Skilbrei 2012). If they enter rivers to spawn (Sægrov et al. 1997), they may compromise the genetic integrity of local wild salmon populations (Crozier 1993, Clifford et al. 1998, Skaala et al. 2006, Glover et al. 2013). Young farmed salmon that escape from net

*Corresponding author: ove.skilbrei@imr.no pens in the sea as smolts or post-smolts during spring and summer migrate rapidly towards the feeding areas of wild salmon in the open sea, returning after 1 to 3 yr to spawn (Skilbrei 2010a,b). The spawning behaviour and success of these escapees are believed to be similar to those of wild salmon, in contrast to the less optimal behaviour of adult fish that escape from the pens just prior to their entry into the river (Fleming et al. 1996, 1997).

Do escaped smolts represent a high proportion of the escaped salmon that enter in rivers to spawn, or have most of the escapees escaped recently from net pens as adults? According to Norwegian escape statistics, $<4 \%$ of escapees escaped as smolts between

(C) The authors 2015. Open Access under Creative Commons by Attribution Licence. Use, distribution and reproduction are unrestricted. Authors and original publication must be credited. 
2005 and 2011 (Skilbrei et al. 2015). However, escaped salmon can leave the net pens unreported and possibly also undetected by the fish farmer (Skilbrei \& Wennevik 2006, Glover 2010, Zhang et al. 2013), and therefore estimates of actual escapes of both smolts and adults are significantly higher than reported numbers (Skilbrei et al. 2015). Knowledge of the escape history of these salmon is important for risk assessments and for the development of strategies to prevent future escapes and reduce their ecological impacts.

A suitable method of monitoring the escape history of Atlantic salmon is needed. Reading scales is an effective means of distinguishing between escaped farmed and wild salmon due to the much faster growth rate of farmed juvenile salmon in freshwater (Lund \& Hansen 1991), but the age and time of escape of farmed fish is often difficult to determine from scales (Erkinaro et al. 2010). Scale analysis depends on the assumption that farmed salmon exhibit a seasonal rhythm in growth similar to that of wild salmon. However, this interpretation may be obscured by aquaculture practices. Smolt development can be affected by photoperiod manipulations in the hatcheries, and smolts are transferred to net pens in the sea at various sizes from early spring to late autumn (Berge et al. 1995, Duston \& Saunders 1995, Skilbrei 2013). Furthermore, outbreaks of disease on farms may influence growth patterns (Damsgård et al. 1998, McLoughlin \& Graham 2007). Complementary methods to scale readings are therefore required.

Genetic methods have been used to trace escaped farmed salmon to the fish farm of origin (Glover et al. 2008, Glover 2010). This approach uses genetic samples from fish farms for comparisons with recaptured escaped salmon, but has primarily been used to trace recently escaped salmon and does not provide information about the time of escape. Several methods have been used to discriminate between wild and farmed salmon, such as fatty acid (FA) distributions (Axelson et al. 2009), chemical profiling with elemental analysis (Anderson et al. 2010), ${ }^{13} \mathrm{C}$ nuclear magnetic resonance (Aursand et al. 2009), and the use of stable isotopes (Dempson \& Power 2004, Schröder \& de Leaniz 2011). These methods all depend on differences in the composition of the food consumed by wild and farmed fish. Therefore, they have the potential to be used to study the escape history of farmed fish in more detail, but have not yet been fine-tuned enough to do so.

The use of FA profiles can be employed to distinguish between salmon that escaped early in their life versus as adults, because of the use of terrestrial lipids in salmon feed. These terrestrial lipids are low in typical marine long-chain polyunsaturated FAs (PUFAs) and high in medium-chain PUFAs 18:2n-6 and 18:3n-3 (Olsen et al. 2013). The depot lipids (triacylglycerols, TAG) mirror the composition of the feed and give the best resemblance to dietary history compared with analysis of total lipids, especially in mature salmon with low lipid content (Olsen et al. 2013). The content of the TAG FA 18:2n-6 in farmed salmon is typically above $10 \%$. In contrast, the level of $18: 2 n-6$ was low $(<2.5 \%)$ in sea-ranched salmon in Iceland (Jonsson et al. 1997) and in farmed salmon released as smolts and recaptured in Norway after 1 to 3 yr at sea (Olsen \& Skilbrei 2010).

Quantifying tissue lipids may therefore provide a good estimate of an individual's feeding history, at least if the intention is to distinguish between escapes of young fish that have grown to adult size in the Norwegian Sea and recently escaped adult salmon. However, salmon of any size may escape during the production cycle from young to adult. If a fish escapes at an intermediate size and then switches to natural prey, it could be expected to present a more diffuse lipid profile. Therefore, to estimate the size at escape, we need to estimate the elimination rate of terrestrial FAs after the switch to natural prey.

We tested the use of lipid profiling to monitor the escape histories of farmed salmon captured in salmon rivers. We also report results of a laboratory experiment that examined the development of the FA profiles of farmed salmon after replacement of the terrestrial lipids in their feed with fish oils, in order to estimate the size of the escapee at the time of the switch from food pellets to natural prey.

\section{MATERIALS AND METHODS}

\section{Feed experiment}

Feed preparation. A total of 3 experimental terrestrial diets based on linseed, rapeseed and soya oil (produced by Nofima) were fed to the fish during a priming phase (Table 1). Thereafter, all fish were fed the same fishmeal/fish oil-based diet. All diets were made using double-screwed extrusion with similar standards and additives as commercial diets. The initial pellets $(4.5 \mathrm{~mm})$ had a lipid content of $12 \%$ in order to ensure that the requirements of essential FAs were met. Thereafter, $22 \%$ of the various terrestrial oils were coated using a vacuum. The fishmeal/ fish oil-based diet $(8 \mathrm{~mm}$ ) was produced in a similar way, and were based on the FA composition in wild- 
Table 1. Composition and amount of ingredients used to produce the experimental diets based on soya, linseed, rapeseed and marine fish oils. The calculated chemical composition of the 3 terrestrial diets $(4.5 \mathrm{~mm}$ pellets) and the marine diet (8.0 $\mathrm{mm}$ pellets) is also given

\begin{tabular}{|c|c|c|c|c|c|c|c|}
\hline \multirow{2}{*}{$\begin{array}{l}\text { Ingredient } \\
\qquad \text { Diet: }\end{array}$} & \multicolumn{4}{|c|}{ Amount of ingredient (g per $100 \mathrm{~g}$ of diet) } & & \multicolumn{2}{|c|}{$\begin{array}{l}\text { Chemical composition } \\
\text { (by dry weight) }\end{array}$} \\
\hline & Soya & Linseed & Rapeseed & Marine & & $4.5 \mathrm{~mm}$ pellets & $8.0 \mathrm{~mm}$ pellets \\
\hline Fish meal 29/10 & 30.9 & 30.9 & 30.9 & 20.9 & Protein & 48.3 & 48.1 \\
\hline Fish meal 122/11 & 30.0 & 30.0 & 30.0 & 40.0 & Lipid & 30.9 & 30.8 \\
\hline Wheat 115/11 & 14.5 & 14.5 & 14.5 & 14.5 & Carbohydrate & 12.4 & 12.3 \\
\hline Vitamin mixture ${ }^{a}$ & 2.0 & 2.0 & 2.0 & 2.0 & Ash & 8.6 & 8.8 \\
\hline Mineral mixture ${ }^{b}$ & 0.5 & 0.5 & 0.5 & 0.5 & & & \\
\hline Carophyll pink & 0.04 & 0.04 & 0.04 & 0.04 & & & \\
\hline Fish oil & & & & 22.0 & & & \\
\hline Soybean oil & 22.0 & & & & & & \\
\hline Linseed oil & & 22.0 & & & & & \\
\hline Rapeseed oil & & & 22.0 & & & & \\
\hline \multicolumn{8}{|c|}{ 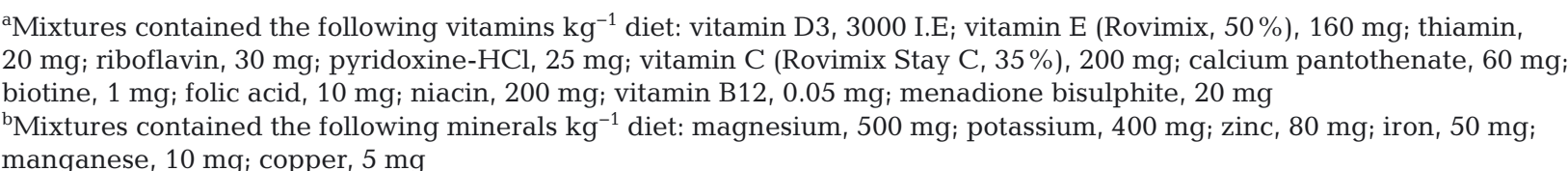 } \\
\hline
\end{tabular}

caught salmon (Olsen \& Skilbrei 2010). The chemical compositions of the 2 diets used are shown in Table 1.

Fish. In June 2011, 210 Atlantic salmon Salmo salar (NLA strain; Norwegian breeding programme) were transferred to six $1.5 \times 1.5 \times 1 \mathrm{~m}^{3}$ standard fiberglass tanks equipped with feed collectors, supplied with aerated seawater (mean $\pm \mathrm{SD} 9 \pm 0.5^{\circ} \mathrm{C}$ ) and kept under a $12 \mathrm{~h}$ light:12 $\mathrm{h}$ dark daylight regime at the Matre Research Station, Norway. The fish were weighed (mean \pm SD: $304 \pm 50 \mathrm{~g}$ ) $1 \mathrm{~d}$ before the start of the experiment (29 July 2011). The fish were fed the 3 experimental terrestrial diets in duplicate tanks every day using disc feeders from 08:00 to $12: 00 \mathrm{~h}$ from 23 July to 24 October 2011 (92 d). Thereafter, all fish were fed the marine diet until the end of the experiment on 11 July 2012, at which point there were 128 fish remaining in the experiment.

All fish were measured for length and weight on 29 July 2011, 24 October 2011, 17 to 21 February 2012 and 11 July 2012. Tissue samples were taken from 4 to 6 individuals in each treatment group (2-4 tank $\left.{ }^{-1}\right)$ on 24 October 2011, 24 November 2011, 6 January 2012, 17 February 2012, 25 April 2012 and 11 July 2012. The fish were first anaesthetized with a strong solution of MS222 and then killed by a stroke to the head. On 20 February, all fish were tagged with T-bar tags of different colours (according to treatment group), and transferred to a $5 \mathrm{~m}$ diameter fiberglass tank for the remainder of the experiment. During sampling, they were anaesthetized in a $0.4 \%$ solution of MS222 and measured to the nearest $0.1 \mathrm{~g}$ and $1 \mathrm{~mm}$.

\section{Capture of escaped farmed salmon}

Escaped farmed salmon were collected from 6 rivers that drain into the Hardangerfjord basin (Table 2). This fjord system houses a large aquaculture industry (Fig. 1) that produced 80000 t of salmon in 2014 (Skaala et al. 2014). There is a high incidence of escaped farmed salmon in the spawning population of these rivers. The River Etne supports by far the largest wild salmon stock in the region, and it also attracts the highest numbers of escapees (Vollset et al. 2014).

Escaped salmon were captured in the River Etne from 27 September to 10 November 2011, and in 2 bag-nets operating near the River Etne estuary from 6 August to 15 October 2011 by a fishery intended to target and remove escaped salmon. Wild salmon unintentionally taken in the bag-nets were used as controls for the FA analysis. Escaped salmon and some wild salmon were also captured in the Rivers

Table 2. Salmo salar. Number of salmon from each location that were analyzed for fatty acid composition. Fish were identified as escaped farmed (EF) or wild salmon by reading scales

\begin{tabular}{|lcc|}
\hline & EF salmon & Wild salmon \\
\hline River Etne & 183 & 36 \\
River Steinsdal & 25 & 1 \\
River Opo & 34 & 5 \\
River Kinso & 9 & 0 \\
Total & 246 & 42 \\
\hline
\end{tabular}




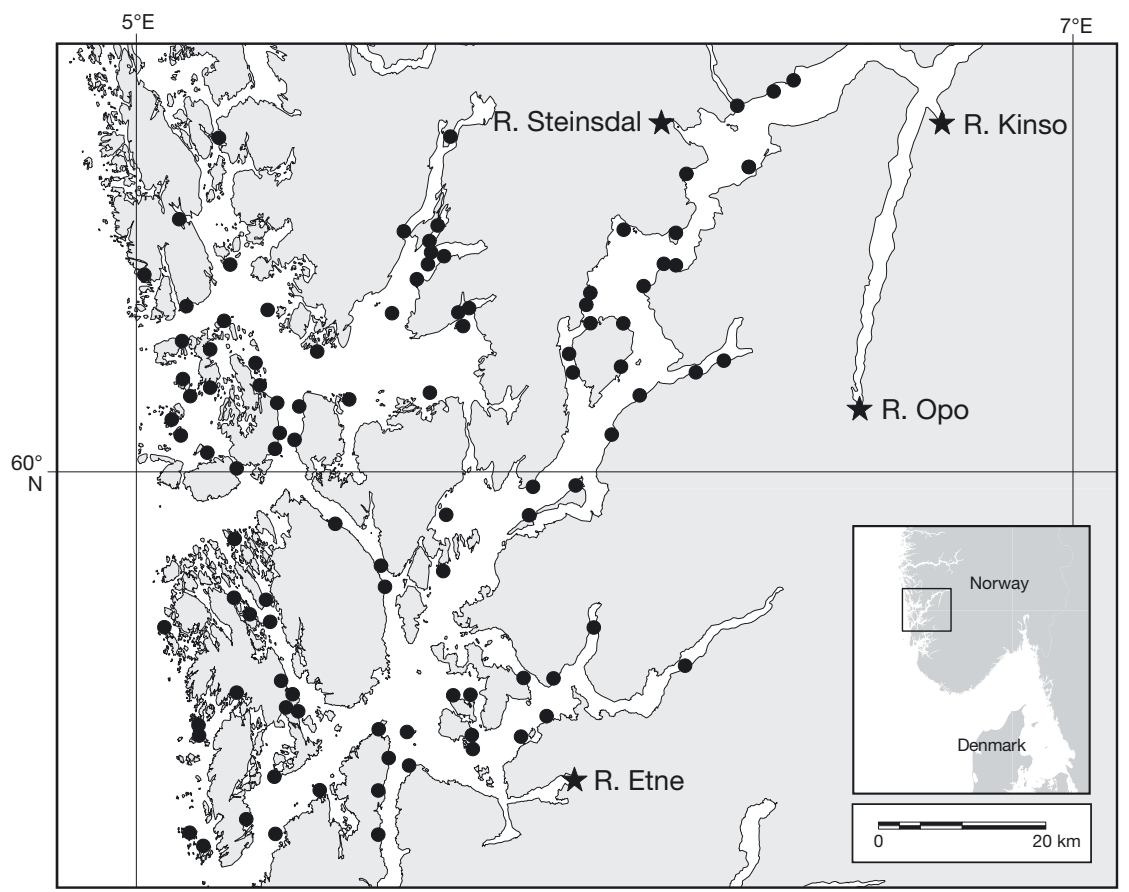

Fig. 1. Sites of salmon farming in Hardangerfjord basin (southwestern Norwegian coast) and surrounding areas (source: Norwegian Directorate of Fisheries), and location of rivers where samples of escaped farmed fish were collected

Steinsdal, Opo and Kinso (see Fig. 1) from 5 September to 16 November 2011.

The fish were categorized as wild or farmed salmon according to the scale-reading method described by Lund \& Hansen (1991) and Fiske et al. (2005). The most important criteria for the identification of escaped farmed salmon were smolt size, smolt age and transition from fresh to salt water. In addition, a detailed analysis of sea (winter) bands of a sample of 61 escaped farmed salmon was performed. It was assumed that the presence of irregularities in sea growth (i.e. a period of reduced growth that did not look like a winter band), was indicative of the time of escape. The fish were grouped into the following 4 categories: (1) escaped early in life (i.e. of smolt-like size), (2) recently escaped, (3) escaped at an intermediate size (between smolt size and size at capture) and (4) recent/intermediate escape group.

\section{Escape event with large broodstock salmon}

In late September 2011, a fish farm reported to the authorities that 1937 broodstock salmon with a mean size of $\sim 10 \mathrm{~kg}$ (largest individuals being almost $16 \mathrm{~kg}$ ) had escaped from a fish farm in the fjord basin. The swimming distance from the broodstock farm to the
River Etne is $\sim 18 \mathrm{~km}$. According to the fish farmer, the fish had been fed standard fish food until December 2010, and thereafter Skretting Vitalis SA until 25 July 2011, when feeding was stopped due to the low appetite of the maturing fish. Skretting Vitalis SA is a specialized broodstock feed with a high content of marine fish oils and a relatively low proportion of terrestrial ingredients, which the producer recommend during the final 9 to 12 mo before spawning.

\section{FA analysis}

In accordance with the recommendations of Olsen et al. (2013), the adipose fin was used for TAG-derived FA profiling of the river-caught salmon. A total of 251 escapees and 42 wild salmon were analysed, and 14 samples of food pellets from different producers collected at various fish farms were analysed for comparison. Lipids were extracted from the adipose fin (field trial) or white muscle posterior to the pectoral fin (feeding experiment) of individual fish according to Folch et al. (1957), and stored under nitrogen at $-80^{\circ} \mathrm{C}$ until analysis. TAGs were separated from the total lipid by high-performance thin-layer chromatography (HPTLC) using the neutral solvent system of Olsen \& Henderson (1989). All samples were methylated, and the respective fatty acid methyl esters (FAME) were analysed on a HP-7890A gas chromatograph (Agilent) with a flame ionization detector (GC-FID) as described previously in Olsen et al. (2004) for the feeding experiment, and in Meier et al. (2006) for the field trial. In total, 61 well-defined peaks in the chromatogram were selected, and identified by comparing retention times with a FAME standard (GLC-463 from Nu-Chek Prep) and retention index maps and mass spectral libraries (GC-MS) (www.chrombox.org/index.html) performed under the same chromatographic conditions as the GC-FID (Wasta \& Mjøs 2013). Chromatographic peak areas were corrected by empirical response factors calculated from the areas of the GLC-463 mixture. The chromatograms were integrated using the EZChrom Elite software (Agilent Technologies). The 36 FAs with a content higher than $0.2 \%$ of total FA in the samples were included in the analysis. 


\section{Relationships between fish size, diet and FA levels}

The decline in terrestrial FAs after the diet change from the experimental terrestrial to the fish oil-based pellets was plotted and compared with the dilution model of Robin et al. (2003). According to these authors, the dilution of an initial quantity of a mixture of FAs by an increasing quantity of a new mixture can be logically described by the following equation for each FA:

$$
P i_{t}=P i_{\mathrm{f}}+\left(P i_{0}-P i_{\mathrm{f}}\right) /\left(Q_{t} / Q_{0}\right)
$$

where $P i$ is the percentage of the FA $i$, with 0 for its original (initial) value and $\mathrm{f}$ for its final value. $Q_{0}$ represents the initial quantity of total FAs, and $Q_{t}$ the same at time $t$. By assuming that $W_{t} / W_{0}$ (where $W$ is the weight of the fish) can be used as an approximation for $Q_{t} / Q_{0}$, and presenting $P i_{t}$ as relative values from $P i_{0}=100 \%$ to $P i_{\mathrm{f}}=0 \%$, the formula for the dilution model simplifies to:

$$
W_{t} / W_{0}=100 / P i_{t}
$$

Based on the weight and percentage of the FA $18: 2 n-6$ of escaped farmed salmon at the time of river capture (i.e. $W_{t}$ and $P_{t}$ ), a logarithmic function between fish size and relative content of 18:2n-6 derived from the diet experiment (see 'Results') was applied to estimate the size of escaped farmed salmon at the time of switch from commercial pellets to natural food (i.e. $W_{0}$ ). In the model, $18: 2 \mathrm{n}-6=12 \%$ of the total FA corresponds to $P_{0}$ (recalculated to $100 \%$ in the model), and $18: 2 \mathrm{n}-6=2.5 \%$ corresponds to $P_{\mathrm{f}}(0 \%$ in the model). $18: 2 \mathrm{n}-6=2.5 \%$ was chosen because this appeared to be close to the maximum level in wild fish, and is used as an estimate of the level in farmed escaped fish, where this FA has been 'washed out'. 18:2n-6 = 12\% represents a normal level of this FA in salmon food pellets, and therefore estimates the level of this FA at the time of escape.

\section{Classification of time of escape of farmed salmon}

By taking scale readings and the level of the FA 18:2n-6 into account, the fish were classified into 4 main categories: (1) wild salmon, (2) farmed salmon believed to have escaped at an early age, with levels of $18: 2 n-6<2.5 \%$, (3) recently escaped farmed salmon with 18:2n-6>7\% and (4) fish with intermediate levels of $18: 2 n-6$ (i.e. between 2.5 and $7 \%$ ) that are believed to have escaped between the 2 former stages.

\section{Statistics}

The mean weights of the 3 terrestrial diet groups and differences between tanks were tested using general linear model (GLM) and Newman-Keuls multiple test (Statistica v.12, StatSoft). There were no significant effects of Tank during the first part of the experiment until all fish were reared in 1 common tank, so Tank was not included in the further comparisons. Normality was checked by normal probability plots. FA compositions of the tank trial were analysed using GLM (SPSS v.21) and Tamhane's post hoc test assuming unequal variances. Principal Component Analysis (PCA) was carried out using Sirius v.8.1 (PRS AS). Before PCA, the relative values (i.e. percent of the sum) were scaled by dividing each value by the mean of the values of all samples for that particular FA, with the intention of leveling out the quantitative difference among the FAs, leaving them all to vary around 1. All FAs $>0.2 \%$ were included in the PCA (36 FAs). Score and loading plots from PCA analysis were generated in Sirius.

\section{RESULTS}

\section{Feed experiment}

The fish grew from an average $( \pm \mathrm{SD})$ weight of $304 \pm 50 \mathrm{~g}$ in July to $844 \pm 131 \mathrm{~g}$ in October, when the diets were changed to a fully marine fish meal and oil-based diet. From October until the end of the experiment in July, the fish grew to an average weight of $3359 \pm 591$ g (Fig. 2). There were no significant differences between the mean sizes of the 3 terrestrial diet groups at the start of the experiment (GLM; $F=1.18, \mathrm{p}=0.31$ ), in February $(F=0.08, \mathrm{p}=0.93)$ or at the end of the experiment in July $(F=1.21, \mathrm{p}=0.30)$ (NewmanKeuls tests; $\mathrm{p}>0.1$ ).

The terrestrial FA food mixture contained high levels of 18:3n-3, particularly in the linseed oil diet $(40.3 \%), 18: 1 \mathrm{n}-9$ in the rapeseed oil diet $(49.8 \%)$ and $18: 2 n-6$ in the soybean oil diet (40.3\%) (Table 3$)$. The terrestrial diets led to FA profiles in the salmon similar to that in the food (Table 4). In particular, the 18:3n-3 and 18:2n-6 content increased to 26.9 and $12.6 \%$, respectively, in fish fed the linseed oil diet, while the same FAs increased to 3.3 and $32.9 \%$, respectively, in fish fed the soybean oil diet. For those given the rapeseed oil diet, the content of $18: 1 \mathrm{n}-9$ rose to $46.2 \%$. Some elongation and de- 

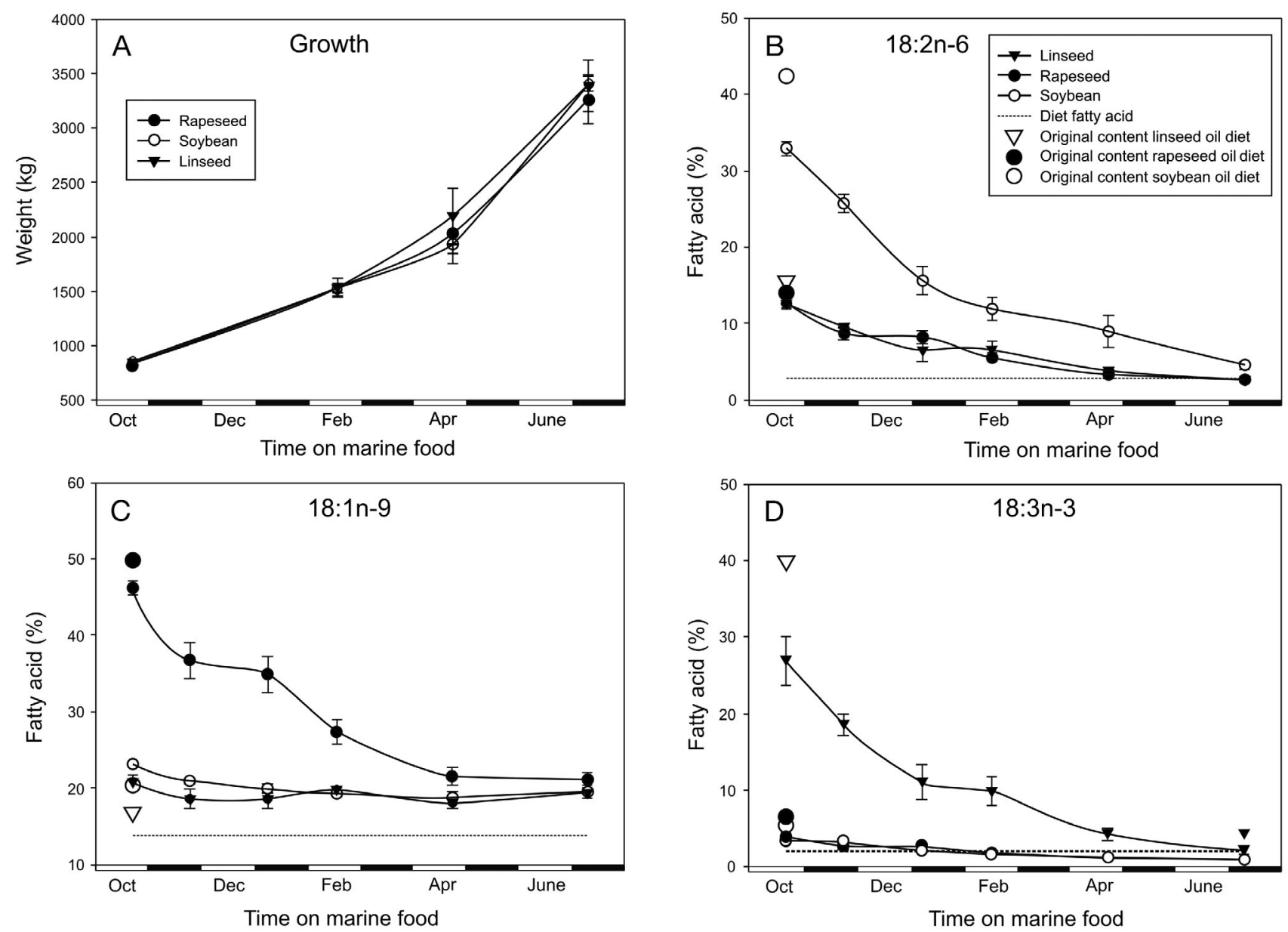

Fig. 2. Salmo salar. (A) Weight of fish and (B-D) relative percentages of the 3 fatty acids (FAs) (B) 18:2n-6, (C) 18:1n-9 and (D) 18:3n-3 in salmon after the shift from the 3 initial feeds based on linseed, rapeseed and soybean oils to a common feed based on marine FAs (see 'Materials and methods' for full description). The content of the 3 FAs in the 3 original diets (large symbols) and in the marine diet (dotted lines) are included

saturation of 18:2n-6 and 18:3n-3 were observed in the TAG of fish fed the linseed oil and soybean oil diets $(18: 2 n-6$ to $20: 2 n-6$, and $18: 3 n-3$ to e.g. $18: 4 n-$ 3 and $20: 4 n-3)$, but the differences were marginal (Table 4).

Feeding the marine-based oil to the fish reduced the level of terrestrial FAs as the size of the fish increased (Fig. 2). At the end of the trial, all the FA profiles were similar (Table 4), although there were small but significant differences between the levels of 18:1n-9, 18:3n-3 and 18:2n-6 (Table 4). The decrease in 18:2n-6 and 18:3n-3 did not completely match a theoretical dilution model $(y=$ $100 / x$, simplified from Robin et al. 2003; see 'Materials and methods'), which predicts how levels decline when fish increase in biomass by consuming feed with a lower content of these FAs (Fig. 3). The decline was more rapid, and was fitted by the logarithmic function $y=4.1583-1.5871 \times \log _{10}(x)$.

\section{FA profiles of salmon caught in rivers}

The levels of $18: 2 n-6$ ranged from 1 to $12 \%$. The distribution of $18: 1 \mathrm{n}-9$ produced a similar picture but displayed larger variability than 18:2n-6 among wild fish and early and intermediate escapees (Figs. 4 \& 5). In addition to escaped farmed salmon believed to have escaped early, late or at an intermediate stage of life, an additional group of large sized salmon with 18:2n- 6 between 6 and $8 \%$ were present (Table 5). They were assumed to have come from the escape of large broodfish that had been fed with a broodstock feed with a lower content of terrestrial oils (Table 6).

Both the differences and similarities between the categories of fish were visualized by including all measured FAs $>0.2 \%(n=36)$ in a PCA. The 2 groups of recently escaped adult fish were clearly distinguishable from the wild fish and early escapees along principal component 1 (PC1), which explained 


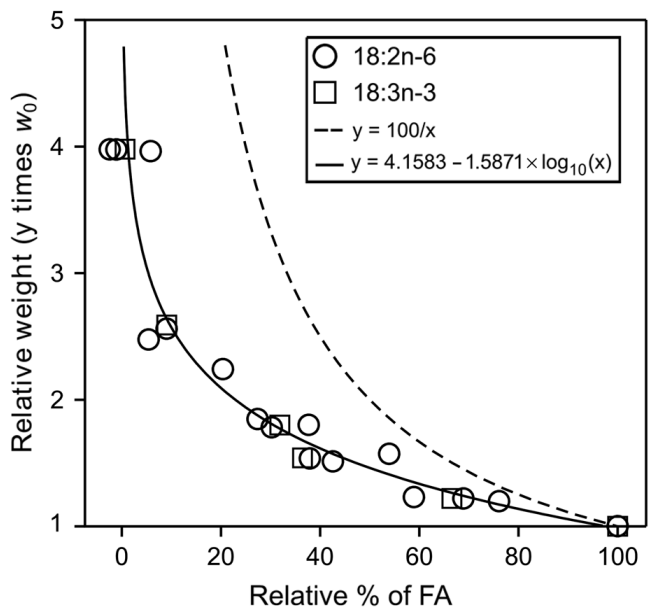

Fig. 3. Salmo salar. Relative change (\%) from original level of the fatty acids (FAs) 18:2n-6 and 18:3n-3 with increased weight ( $y$ times initial weight, $W_{0}$, on 24 October 2011) of the fish after the change of diet to marine feed; $0 \%$ relative FA is defined as the FA level of the marine diet. A logarithmic function is fitted to the data (solid line). A theoretic curve describing how the initial percentage of FAs would be lowered if its reduction had been caused by simple dilution is also shown ( $y=100 / x$; dashed line) (simplified from Robin et al. 2003, see 'Material and methods')

$58 \%$ of the variation in the data (Comp. 1 in Fig. 6). The early escapees had a very similar distribution in the PCA plot compared to the wild fish. The loading plots (Fig. 7) showed that the recently escaped fish were high in the terrestrial FAs $(18: 2 n-6,18: 3 n-3$, 18:1n-9) and their elongation products $(20: 2 n-6$ and $20: 3 n-3)$, while the wild and early escaped fish were dominated by the more typical marine FAs. Along PC2 (Comp. 2), there was no separation between the different groups of fish, but large individual variability was caused by high relative amounts of 22 : 5n-6 and the long-chain monounsaturated FAs (MUFAs; 18:1, $20: 1,22: 1,24: 1$ ) in the upper compartments, and the high relative amounts of saturated FAs (SFAs; 14:0, 15:0 and 16:0) and PUFAs (18:4n-1, 16:2n-4, 18:4n-3, $21: 5 n-3 ， 20: 6 n-3 ， 20: 5 n-3 ， 20$ : $4 n-3)$ in the lower compartments (Fig. 7). Means of all detected FAs are shown in
Table 3. Percentage of total fatty acids (\%) of the terrestrial diets (Lin: linseed oil; Rap: rapeseed oil; Soy: soybean oil) fed to Atlantic salmon from July to October, and the marine diet fed from October to July. SFA: saturated fatty acid; MUFA: monounsaturated fatty acid; PUFA: polyunsaturated fatty acid

\begin{tabular}{|lcccc|}
\hline FA & Lin & Rap & Soy & Marine \\
\hline $14: 0$ & 1.6 & 1.2 & 1.4 & 5.7 \\
$16: 0$ & 8.4 & 7.2 & 12.3 & 13.2 \\
$18: 0$ & 2.3 & 1.9 & 2.7 & 1.5 \\
$16: 1 \mathrm{n}-7$ & 1.5 & 1.4 & 1.4 & 4.7 \\
$18: 1 \mathrm{n}-9$ & 16.5 & 49.8 & 20.4 & 13.8 \\
$18: 1 \mathrm{n}-7$ & 1.2 & 2.6 & 1.5 & 1.9 \\
$20: 1 \mathrm{n}-9$ & 2.5 & 3.1 & 2.3 & 12.4 \\
$22: 1 \mathrm{n}-11$ & 2.8 & 2.7 & 2.6 & 17.4 \\
$22: 1 \mathrm{n}-9$ & 0.2 & 0.3 & 0.2 & 1.0 \\
$24: 1 \mathrm{n}-9$ & 0.2 & 0.2 & 0.2 & 0.8 \\
$18: 2 \mathrm{n}-6$ & 14.0 & 15.6 & 42.3 & 2.8 \\
$20: 2 \mathrm{n}-6$ & 0.1 & 0.1 & 0.0 & 0.3 \\
$20: 4 \mathrm{n}-6$ & 0.1 & 0.0 & 0.0 & 0.7 \\
$18: 3 \mathrm{n}-3$ & 40.3 & 6.2 & 5.4 & 2.0 \\
$18: 4 \mathrm{n}-3$ & 0.6 & 0.4 & 0.3 & 2.0 \\
$20: 4 \mathrm{n}-3$ & 0.1 & 0.1 & 0.1 & 0.4 \\
$20: 5 \mathrm{n}-3$ & 1.7 & 1.6 & 1.6 & 5.4 \\
$22: 5 \mathrm{n}-3$ & 0.2 & 0.1 & 0.1 & 0.6 \\
$22: 6 \mathrm{n}-3$ & 2.7 & 2.5 & 2.5 & 7.1 \\
SFA & 12.8 & 11.4 & 17.3 & 21.2 \\
MUFA & 25.5 & 60.8 & 28.9 & 53.1 \\
n-3 PUFA & 59.9 & 27.0 & 52.7 & 22.3 \\
n-6 PUFA & 14.4 & 16.0 & 42.7 & 4.7 \\
\hline
\end{tabular}

Table 4. Salmo salar. Percentage of total fatty acids (\%) of salmon in October 2011 after feeding the terrestrial diets, and at end of the trial in July 2012 after feeding marine meal. A general linear model (GLM) was used to test differences in FAs between the 3 terrestrial diets for each month. Numbers within each line and between months not sharing common superscript letters are significantly different $(p<0.05)$

\begin{tabular}{|c|c|c|c|c|c|c|}
\hline \multirow[t]{2}{*}{ FA } & \multicolumn{3}{|c|}{-22 October } & \multicolumn{2}{|r|}{ - 11 July } & \multirow[b]{2}{*}{ Soy } \\
\hline & Lin & Rap & Soy & Lin & Rap & \\
\hline $14: 0$ & $1.8 \pm 0.3^{\mathrm{a}}$ & $1.4 \pm 0.1^{\mathrm{ab}}$ & $1.3 \pm 0.1^{b}$ & $5.1 \pm 0.1$ & $5.0 \pm 0.1$ & $4.8 \pm 0.1$ \\
\hline $16: 0$ & $11.0 \pm 0.3^{b}$ & $9.7 \pm 0.2^{\mathrm{a}}$ & $13.6 \pm 0.5^{\mathrm{c}}$ & $15.2 \pm 0.7$ & $14.9 \pm 0.6$ & $14.8 \pm 0.6$ \\
\hline $18: 0$ & $3.3 \pm 0.1^{\mathrm{a}}$ & $2.6 \pm 0.1^{b}$ & $3.8 \pm 0.5^{\mathrm{c}}$ & $2.9 \pm 0.3$ & $2.5 \pm 0.2$ & $3.0 \pm 0.5$ \\
\hline $16: 1 n-7$ & $2.0 \pm 0.2$ & $1.9 \pm 0.1$ & $1.7 \pm 0.2$ & $5.4 \pm 0.1$ & $5.4 \pm 0.2$ & $5.3 \pm 0.1$ \\
\hline $18: 1 n-9$ & $20.6 \pm 1.0^{\mathrm{b}}$ & $46.2 \pm 0.9^{a}$ & $23.1 \pm 0.3^{\mathrm{c}}$ & $19.4 \pm 0.6^{a}$ & $21.1 \pm 0.8^{\mathrm{b}}$ & $19.5 \pm 0.2^{\mathrm{a}}$ \\
\hline $18: 1 n-7$ & $1.8 \pm 0.1^{\mathrm{a}}$ & $2.9 \pm 0.1^{b}$ & $2.4 \pm 0.1^{\mathrm{c}}$ & $2.5 \pm 0.1$ & $2.6 \pm 0.1$ & $2.5 \pm 0.5$ \\
\hline $20: 1 n-9$ & $3.3 \pm 0.2^{\mathrm{a}}$ & $4.7 \pm 0.4^{\mathrm{b}}$ & $3.4 \pm 0.1^{\mathrm{a}}$ & $11.7 \pm 0.9$ & $12.3 \pm 0.1$ & $12.1 \pm 0.1$ \\
\hline $22: 1 n-11$ & $3.0 \pm 0.2$ & $2.8 \pm 0.4$ & $2.5 \pm 1.0$ & $13.8 \pm 0.5$ & $13.5 \pm 0.5$ & $13.2 \pm 0.1$ \\
\hline $22: 1 n-9$ & $0.4 \pm 0.0$ & $0.4 \pm 0.0$ & $0.3 \pm 0.0$ & $1.0 \pm 0.0$ & $1.0 \pm 0.0$ & $0.8 \pm 0.3$ \\
\hline $24: 1 n-9$ & $0.3 \pm 0.0$ & $0.4 \pm 0.0$ & $0.3 \pm 0.0$ & $0.8 \pm 0.0$ & $0.8 \pm 0.0$ & $0.7 \pm 0.0$ \\
\hline $18: 2 n-6$ & $12.6 \pm 0.1^{\mathrm{a}}$ & $12.8 \pm 0.8^{\mathrm{a}}$ & $32.9 \pm 0.9^{\mathrm{b}}$ & $2.5 \pm 0.2^{\mathrm{a}}$ & $2.6 \pm 0.3^{\mathrm{a}}$ & $4.5 \pm 0.5^{b}$ \\
\hline $20: 2 n-6$ & $0.8 \pm 0.2^{\mathrm{a}}$ & $1.2 \pm 0.1^{\mathrm{b}}$ & $2.4 \pm 0.0^{\mathrm{c}}$ & $0.5 \pm 0.1$ & $0.4 \pm 0.1$ & $0.5 \pm 0.0$ \\
\hline $20: 4 n-6$ & $0.1 \pm 0.0$ & $0.1 \pm 0.0$ & $0.1 \pm 0.0$ & $0.2 \pm 0.0$ & $0.2 \pm 0.0$ & $0.2 \pm 0.0$ \\
\hline $18: 3 n-3$ & $26.9 \pm 2.3^{\mathrm{a}}$ & $3.9 \pm 0.5^{b}$ & $3.3 \pm 0.1^{\mathrm{b}}$ & $2.1 \pm 0.4^{a}$ & $1.0 \pm 0.1^{\mathrm{b}}$ & $1.0 \pm 0.6^{b}$ \\
\hline $18: 4 n-3$ & $1.1 \pm 0.1^{\mathrm{a}}$ & $0.5 \pm 0.1^{\mathrm{b}}$ & $0.4 \pm 0.0^{\mathrm{b}}$ & $0.9 \pm 0.0$ & $0.9 \pm 0.0$ & $0.9 \pm 0.0$ \\
\hline $20: 4 n-3$ & $1.3 \pm 0.1^{\mathrm{a}}$ & $0.5 \pm 0.0^{\mathrm{b}}$ & $0.4 \pm 0.0^{\mathrm{b}}$ & $1.0 \pm 0.0$ & $1.0 \pm 0.0$ & $1.0 \pm 0.0$ \\
\hline $20: 5 n-3$ & $1.2 \pm 0.2^{\mathrm{a}}$ & $0.9 \pm 0.1^{b}$ & $0.8 \pm 0.2^{\mathrm{b}}$ & $3.0 \pm 0.1$ & $3.0 \pm 0.1$ & $3.2 \pm 0.2$ \\
\hline $22: 5 n-3$ & $0.4 \pm 0.0$ & $0.3 \pm 0.0$ & $0.3 \pm 0.0$ & $1.3 \pm 0.1$ & $1.3 \pm 0.0$ & $1.3 \pm 0.0$ \\
\hline $22: 6 n-3$ & $3.1 \pm 0.4$ & $2.8 \pm 0.3$ & $2.6 \pm 0.2$ & $6.6 \pm 0.4$ & $6.7 \pm 0.1$ & $6.8 \pm 0.3$ \\
\hline
\end{tabular}




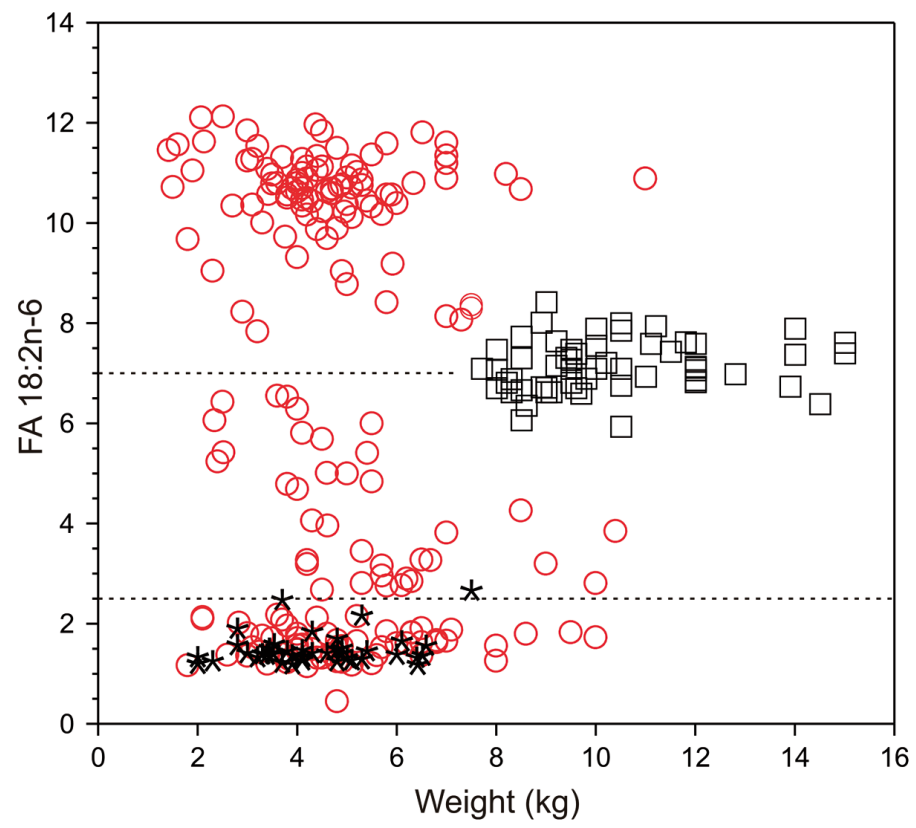

Fig. 4. Salmo salar. Level of the fatty acid (FA) 18:2n-6 (\%) versus body weight of escaped farmed salmon (red circles), presumably escaped brood fish (black squares) and wild salmon (asterisks). FA levels used to categorise fish into smolt-escapees (lower group), intermediate escapees and recently escaped adults (upper group) are indicated by dotted lines

Table S1 in the Supplement at www.int-res.com/ articles/suppl/q007p001_supp.pdf.

The use of $18: 2 n-6$ to categorize escaped farmed salmon with respect to the time of escape did not match well with an alternative categorizing of 61 escaped farmed salmon based on scale readings. Scale readings appeared to be inconsistent with 18:2n-6 levels for at least $40 \%$ of the individuals in all escape groups (Fig. 8).

Most of the intermediate escapees were estimated to have been between 1 and $3 \mathrm{~kg}$ when they switched from commercial food pellets to natural feed (see 'Material and methods' for calculations), and between 3 and $11 \mathrm{~kg}$ when captured in rivers (Fig. 9).

\section{FA profiles of food pellets}

The content of FAs like 18:1n-9 and 18:2n-6 were high, but variable, in food pellets from different producers obtained from fish farms. The content of the typical terrestrial lipids were lower in food for small fish (smolts) and broodfish (Table 6). All detected FAs in the food are shown in Table S2 in the Supplement at www.int-res.com/articles/suppl/q007p001_ supp.pdf.

\section{DISCUSSION}

This study demonstrates that analysis of FAs is a powerful tool to monitor the escape history of escaped farmed Atlantic salmon, enabling us to distinguish between fish that escaped at different stages during the production cycle, from the juvenile and post-smolt stages to large adult salmon. It was possible to observe the effects of the initial priming of the FAs up to 9 mo (end of the trial), or until the fish had grown to 4 times their initial weight, provided the FAs had high initial values. The pattern of disappearance of $18: 1 \mathrm{n}-9$ was different from that of $18: 2 \mathrm{n}-6$ and 18:3n-3. The high background level of $18: 1 n-9$ is most likely due to adjustment of the synthesis or the metabolism since 18:1n-9 is an important product of the de novo synthesis being deposited in salmonid tissues (Olsen et al. 1991).

Normally, it is assumed that FA oxidation for energy is directly fuelled by extracellular FAs with only minimal contribution from the intracellular TAG pool (Gibbons et al. 2000). This means that the level of plant FAs should decrease in fish on a marine diet as a function of dilution. This was, however, not the case in the present study, were the FAs 18:2n-6 and 18:3n-3 disappeared at a rate ca. $30 \%$ faster than expected from a pure dilation model (Robin et al. 2003). This indicates some TAG turnover despite being nutritional sufficient, and probably reflects the fact that hormone selective lipase is active in adipose tissues and is regulated by factors other than diet alone (Weil et al. 2013). Observations have also suggested that these particular FAs are reduced at a higher rate than other FAs following dilution, indicating selective catabolism from the tissue (Robin et al. 2003, Jobling 2003, 2004). This is also evident in some salmon trials that used finishing diets (Bell et al. 2003). The dilution model may overestimate their content in the tissues, as was the case in the present study. We therefore used a modification of the model, i.e. the logarithmic function fitted to our data when estimating size at diet change of river-captured escaped farmed salmon.

Most of the escaped farmed salmon had either escaped early in life or relatively recently as large salmon weighing 2 to $14 \mathrm{~kg}$. Only $15 \%$ appear to have escaped after the post-smolt stage, then switched to natural prey and continued growth until maturity. This is in accordance with the following tagging/ release experiments. Post-smolts that escape during their first summer in net pens in seawater may return to freshwater to spawn after 1 to $3 \mathrm{yr}$ at sea (Skilbrei 2010a,b), with much higher long-term survival rates 


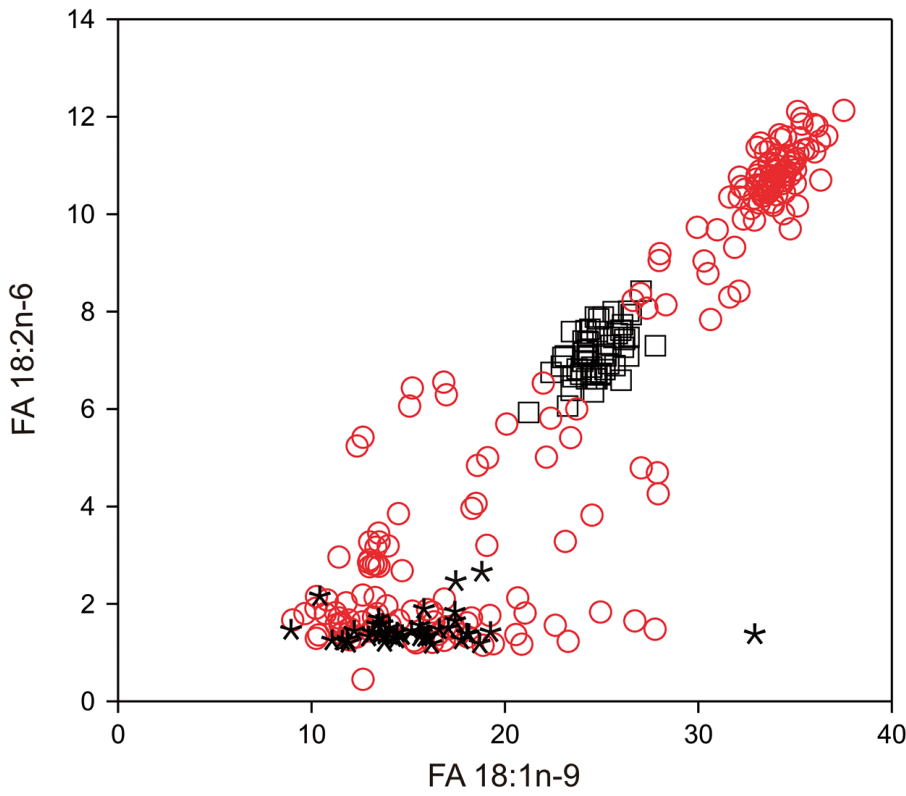

Fig. 5. Salmo salar. Level of fatty acids (FAs, in \%) 18:2n-6 against 18:1n-9 for escaped farmed salmon (red circles), presumably escaped brood fish (black squares) and wild salmon (asterisks) than adult escapees (Skilbrei et al. 2015). Reports have showed that the stomachs of most escaped Atlantic salmon are empty (Hislop \& Webb 1992, Soto et al. 2001, Morton \& Volpe 2002, Abrantes et al. 2011) and 2 studies demonstrated that the FA profile in adult escapees was similar to those given fish feed (Olsen \& Skilbrei 2010, Abrantes et al. 2011). For these reasons, it has been suggested that fully grown salmon have a limited ability to switch to natural prey if released, that immature fish will suffer from high mortality, and that fish that have started the sexual maturation process at the time of escape will have a much higher chance of surviving until they can enter a river to spawn, normally in the same year that they escaped (Skilbrei et al. 2015). The present study supports these suggestions.

FA profiles of large salmon showing intermediate levels of lipids characteristic of terrestrial oils suggest that some fish that escaped after the post-smolt stage were able to switch to natural food. It is not known whether these fish switched rapidly to natural prey, but behavioural and other data suggest that the time of year of escape may influence their ability and opportunity to do so. Migratory behaviour in farmed salmon is stimulated during long and increasing photoperiods, and is weakened in the autumn (Skilbrei 2010b, Skilbrei et al. 2014), so spring and summer escapees move more rapidly towards the open sea, far from fish farms, and must be able to switch to natu-

Table 6. Content of selected fatty acids (FAs) (>4\%) in salmon food pellets obtained from fish farms between 2011 and 2013. All FAs are presented in Table S2 in the Supplement at www.int-res.com/articles/suppl/q007p001_supp.pdf

\begin{tabular}{|c|c|c|c|c|c|c|c|c|c|}
\hline Producer & Recommended use & $16: 0$ & $18: 1 n-9$ & $20: 1 n-9$ & $22: 1 n-11$ & $18: 2 n-6$ & $18: 3 n-3$ & $20: 5 n-3$ & $22: 6 n-3$ \\
\hline Bio Mar Salmon group & Summer, fish $>0.5 \mathrm{~kg}$ & 14.13 & 18.11 & 5.01 & 6.00 & 8.40 & 3.18 & 8.50 & 7.14 \\
\hline Bio Mar Salmon group & All year, large salmon & 10.71 & 26.78 & 6.65 & 9.06 & 10.78 & 3.68 & 4.59 & 4.07 \\
\hline Skretting & All year, fish >0.5 kg & 11.28 & 28.90 & 4.76 & 5.87 & 11.46 & 4.19 & 5.61 & 4.15 \\
\hline EWOS Florø & All year, fish $>0.5 \mathrm{~kg}$ & 9.18 & 34.24 & 5.43 & 6.78 & 12.87 & 5.82 & 3.64 & 3.51 \\
\hline EWOS & Summer, smolts & 18.06 & 8.74 & 1.43 & 1.06 & 4.02 & 1.05 & 14.46 & 8.73 \\
\hline EWOS & Summer, large salmon & 11.87 & 34.14 & 1.43 & 0.55 & 12.12 & 4.45 & 7.01 & 4.27 \\
\hline Bio Mar Salmon group & Winter, large salmon & 9.97 & 37.76 & 2.38 & 1.54 & 15.11 & 5.95 & 4.35 & 4.15 \\
\hline EWOS & Winter, small salmon & 12.04 & 35.99 & 1.90 & 1.51 & 13.05 & 5.30 & 5.03 & 4.17 \\
\hline EWOS & Winter, large salmon & 10.12 & 36.61 & 4.37 & 5.85 & 13.48 & 5.67 & 3.16 & 3.58 \\
\hline EWOS & Winter, large salmon & 10.10 & 37.01 & 4.26 & 5.58 & 13.60 & 5.81 & 3.13 & 3.52 \\
\hline EWOS & Winter, large salmon & 10.72 & 36.50 & 3.70 & 4.12 & 14.22 & 5.49 & 3.03 & 3.25 \\
\hline Skretting & Winter, large salmon & 10.77 & 33.34 & 2.85 & 3.73 & 12.41 & 5.28 & 5.15 & 5.21 \\
\hline Skretting & Winter, small salmon & 10.77 & 23.29 & 6.96 & 13.48 & 9.23 & 3.47 & 4.56 & 5.15 \\
\hline Skretting Vitalis SA & Broodstock feed & 15.67 & 10.37 & 5.84 & 9.31 & 3.98 & 1.20 & 10.63 & 9.07 \\
\hline
\end{tabular}




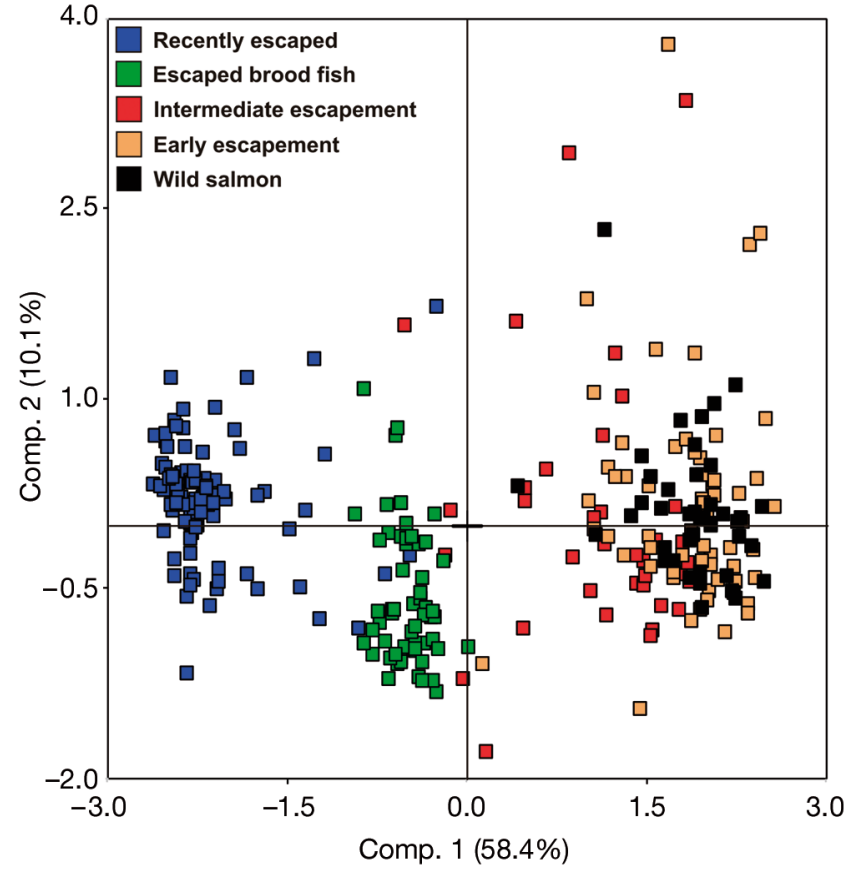

Fig. 6. Salmo salar. Principal component analysis score plot of levels of fatty acids in triacylglycerols of wild salmon (black squares) and farmed salmon escaped recently as brood fish (green) and adults (blue), early in life (orange) or at an intermediate stage (red)

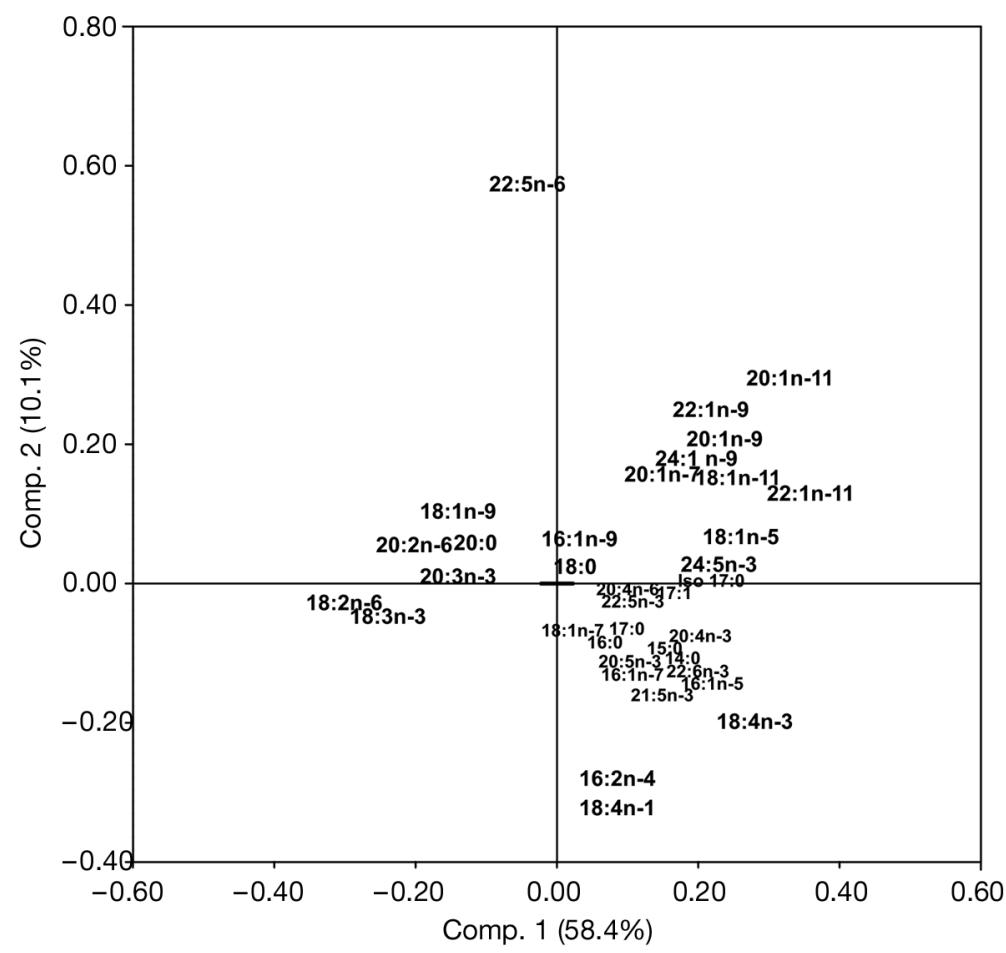

Fig. 7. Salmo salar. Principal component analysis loading plot of fatty acids in triacylglycerols in the adipose fin of farmed and wild salmon (see score plot in Fig. 6) ral prey to survive. Most experimental releases during autumn have demonstrated that the fish disperse relatively rapidly from the escape location (Skilbrei et al. 2010, Skilbrei \& Jørgensen 2010, Solem et al. 2013). However, they may remain in fjords and coastal areas for some time; in one autumn release study, the released farmed salmon stayed in the vicinity of the fish farm and fed on excess food pellets for several months (Olsen \& Skilbrei 2010). Under such circumstances, the switch to natural food will be delayed compared with the time of escape if these fish eventually learn to catch natural prey.

We determined that $24 \%$ of the escapees had escaped early in life, probably as smolts and postsmolts. This contrasts with official escape statistics, which report that very few smolts and post-smolts escape, and supports the suggestion of Skilbrei et al. (2015) that most smolt escape events go unnoticed and/or unreported. Their FA profiles were similar to those of wild salmon with respect to the low levels of the typical terrestrial FAs (18:2n-6, 18:1n-9 and 18:3n-3) and the high contribution of marine FAs such as long-chain MUFAs and long-chain n-3 PUFAs.

Fish from all groups were separated according to the relative amount of the long-chain MUFAs (20:1and 22:1) or short-chain PUFAs (18:4n$1,16: 2 n-4,18: 4 n-3)$, and this indicated different food sources among individuals in the groups. Long-chain MUFAs such as 20:1n-9 and 22:1n-11 originate from zooplankton such as Calanus spp. in the North Atlantic Ocean (Albers et al. 1996, FalkPetersen et al. 2000). These FAs are used as FA trophic markers (FATM) for fish foraging in the Calanus food web (Dalsgaard et al. 2003). The short-chain PUFAs produced by algae (16:2n-4 and 18:4n-1) are FATMs for diatoms, and $18: 4 n-3$ is a FATM for dinoflagellates, and indicate a diet low in the food web (Dalsgaard et al. 2003). Thus, the FA profiles may be used to study diets and trophic interaction in early escaped and wild fish (Petursdottir et al. 2008), however that type of analysis is beyond the scope of the present study.

The accuracy of FA profiling will depend on variability in the composition of different salmon feeds on the market. The feed samples we collected demonstrate that the content of lipids characteristic of terrestrial oils varies among producers, and in specialized feeds used for specific purposes. A higher content of marine oils in pellets given to 


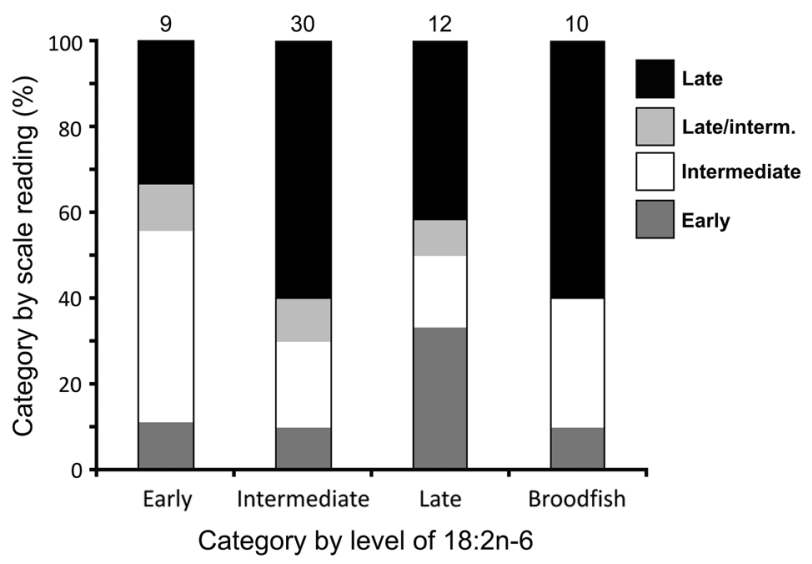

Fig. 8. Comparison between the use of the fatty acid 18:2n-6 and scale readings to group 61 escaped farmed Atlantic salmon according to time of escape. Weight at capture was also used to classify the 'Broodfish' group. Numbers of individuals are given above bars

juvenile fish and smolts during their adaptation to sea water will widen the difference between smolt and adult escapees, while the influence of terrestrial oil on large broodstock fish may be less than expected if the fish have been offered a special diet just prior to spawning. The availability of marine resources used for production of salmon food varies on the global market, so differences in the composition of the feed among producers and over time must be expected. Monitoring this variability in escapehistory studies is recommended, and might be helpful if FA profiling is used to identify the farm of origin of recent escape incidents (Martinez et al. 2009).

The mismatch between the results of scale readings and the use of FA levels to classify escaped

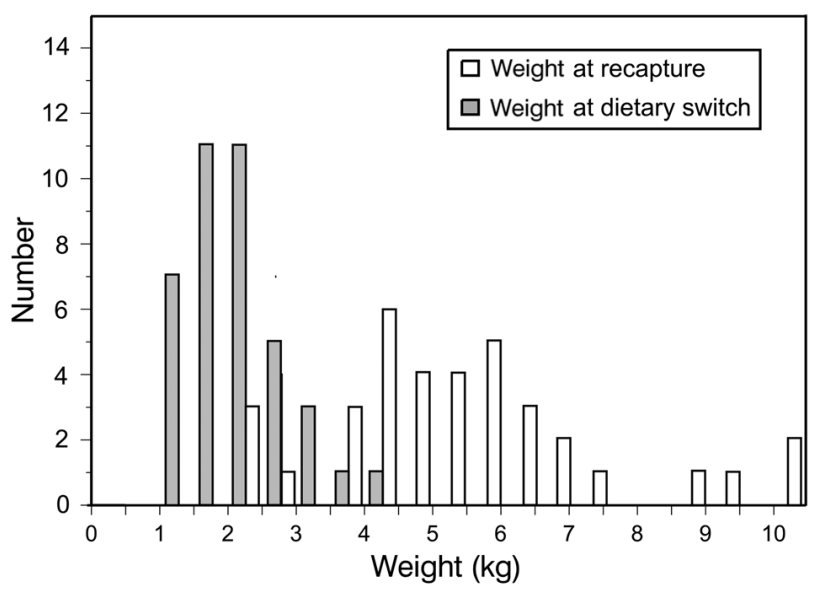

Fig. 9. Salmo salar. Weight at recapture and estimated weight at dietary switch from commercial fish pellets to natural food of escaped farmed salmon with intermediate levels of the fatty acid 18:2n-6 farmed salmon according to stage at escape supports the view of Erkinaro et al. (2010) that the age and time of escape of farmed fish is often difficult to determine from scales alone. We conclude that FA profiling, when used in combination with scale analysis to determine the wild or farmed origin of the fish, is a promising method of studying the history of escaped salmon. This type of information is important for risk analysis and for implementing measures to prevent and mitigate the undesired impacts of farmed salmon escapes. For example, national regulations regarding operational procedures in aquaculture came into force in Norway in 2008 in order to minimize the risk of smolt escapes, since these fish are believed to have higher spawning success than recently escaped salmon (Fleming et al. 1996, 1997). Although smolt or post-smolt escapes are not reflected to any significant degree in the escape statistics (Skilbrei et al. 2015, www.fiskeridir.no), our study indicates that the problem of early life-stage salmon escaping from fish farms has not been completely solved.

Acknowledgements. The study was carried out with financial support of the Institute of Marine Research. We thank the staff at Matre Research Station for maintaining the fish for the feed experiment, Arve Fossen for the fatty acid analyses and Hugh M. Allen for helping with the preparation of the manuscript.

\section{LITERATURE CITED}

Abrantes KG, Lyle JM, Nichols PD, Semmens JM (2011) Do exotic salmonids feed on native fauna after escaping from aquaculture cages in Tasmania, Australia? Can J Fish Aquat Sci 68:1539-1551

Albers CS, Kattner G, Hagen W (1996) The composition of wax esters, triacylgycerols and phospholipids in Arctic and Antarctic copepods: evidence of energetic adaptations. Mar Chem 55:347-358

Anderson KA, Hobbie KA, Smith BW (2010) Chemical profiling with modeling differentiates wild and farm-raised salmon. J Agric Food Chem 58:11768-11774

Aursand M, Standal IB, Prael A, McEvoy L, Irvine J, Axelson DE (2009) ${ }^{13} \mathrm{C}$ NMR pattern recognition techniques for the classification of Atlantic salmon (Salmo salar L.) according to their wild, farmed, and geographical origin. J Agric Food Chem 57:3444-3451

Axelson DE, Standal IB, Martinez I, Aursand M (2009) Classification of wild and farmed salmon using Bayesian belief networks and gas chromatography-derived fatty acid distributions. J Agric Food Chem 57:7634-7639

Bell JG, Tocher DR, Henderson RJ, Dick JR, Crampton VO (2003) Altered fatty acid compositions in Atlantic salmon (Salmo salar) fed diets containing linseed and rapeseed oils can be partially restored by a subsequent fish oil finishing diet. J Nutr 133:2793-2801

Berge ÅI, Berg A, Fyhn HJ, Barnung T, Hansen T, Stefans- 
son SO (1995) Development of salinity tolerance in underyearling smolts of Atlantic salmon (Salmo salar) reared under different photoperiods. Can J Fish Aquat Sci 52:243-251

> Clifford SL, McGinnity P, Ferguson A (1998) Genetic changes in Atlantic salmon (Salmo salar) populations of northwest Irish rivers resulting from escapes of adult farm salmon. Can J Fish Aquat Sci 55:358-363

Crozier WW (1993) Evidence of genetic interaction between escaped farmed salmon and wild Atlantic salmon (Salmo salar L.) in a northern Irish river. Aquaculture 113:19-29

Dalsgaard J, St John M, Kattner G, Muller-Navarra D, Hagen W (2003) Fatty acid trophic markers in the pelagic marine environment. Adv Mar Biol 46:225-340

> Damsgård B, Mortensen A, Sommer AI (1998) Effects of infectious pancreatic necrosis virus (IPNV) on appetite and growth in Atlantic salmon, Salmo salar L. Aquaculture 163:185-193

> Dempson JB, Power M (2004) Use of stable isotopes to distinguish farmed from wild Atlantic salmon, Salmo salar. Ecol Freshw Fish 13:176-184

> Duston J, Saunders RL (1995) Advancing smolting to autumn in age $0+$ Atlantic salmon by photoperiod, and long-term performance in sea water. Aquaculture 135:295-309

Erkinaro J, Niemelä E, Vähä JP, Primmer CR, Brørs S, Hassinen E (2010) Distribution and biological characteristics of escaped farmed salmon in a major subarctic wild salmon river: implications for monitoring. Can J Fish Aquat Sci 67:130-142

Falk-Petersen S, Hagen W, Kattner G, Clarke A, Sargent J (2000) Lipids, trophic relationships, and biodiversity in Arctic and Antarctic krill. Can J Fish Aquat Sci 57: 178-191

FAO (2012) Fisheries and aquaculture software: FishStat Plus - universal software for fishery statistical time series. FAO Fisheries and Aquaculture Department, Rome

Fiske P, Lund RA, Hansen LP (2005) Identifying fish farm escapees. In: Cadrin SX, Friedland KD, Waldman JR (eds) Stock identification methods. Elsevier Academic Press, Amsterdam, p 659-680

> Fleming IA, Jonsson B, Gross MR, Lamberg A (1996) An experimental study of the reproductive behaviour and success of farmed and wild Atlantic salmon (Salmo salar). J Appl Ecol 33:893-905

> Fleming IA, Lamberg A, Jonsson B (1997) Effects of early experience on the reproductive performance of Atlantic salmon. Behav Ecol 8:470-480

Folch J, Lees M, Sloane Stanley GH (1957) A simple method for the isolation and purification of total lipids from animal tissues. J Biol Chem 226:497-509

Gibbons GF, Islam K, Peasse RJ (2000) Mobilisation of triacylglycerol stores. Biochim Biophys Acta 1483:37-57

> Glover KA (2010) Forensic identification of fish farm escapees: the Norwegian experience. Aquacult Environ Interact 1:1-10

> Glover KA, Skilbrei OT, Skaala Ø (2008) Genetic assignment identifies farm of origin for Atlantic salmon Salmo salar escapees in a Norwegian fjord. ICES J Mar Sci 65: 912-920

> Glover KA, Pertoldi C, Besnier F, Wennevik V, Kent M, Skaala $\varnothing$ (2013) Atlantic salmon populations invaded by farmed escapees: quantifying genetic introgression with a Bayesian approach and SNPs. BMC Genet 14:74

- Heuch PA, Mo TA (2001) A model of salmon louse production in Norway: effects of increasing salmon production and public management measures. Dis Aquat Org 45: $145-152$

Hislop JRG, Webb JH (1992) Escaped farmed Atlantic salmon, Salmo salar L., feeding in Scottish coastal waters. Aquacult Fish Manag 23:721-723

Jobling M (2003) Do changes in Atlantic salmon, Salmo salar L., fillet fatty acids following a dietary switch represent wash-out or dilution? Test of a dilution model and its application. Aquacult Res 34:1215-1221

Jobling M (2004) 'Finishing' feeds for carnivorous fish and the fatty acid dilution model. Aquacult Res 35:706-709

> Johansen LH, Jensen I, Mikkelsen H, Bjørn PA, Jansen PA, Bergh $\varnothing$ (2011) Disease interaction and pathogens exchange between wild and farmed fish populations with special reference to Norway. Aquaculture 315:167-186

Jonsson A, Palmadottir H, Kristbergsson K (1997) Fatty acid composition in ocean-ranched Atlantic salmon (Salmo salar). Int J Food Sci Technol 32:547-551

Lund RA, Hansen LP (1991) Identification of released and wild Atlantic salmon, Salmo salar L., using scale characters. Aquacult Fish Manag 22:499-508

> Martinez I, Standal IB, Axelson DE, Finstad B, Aursand M (2009) Identification of the farm origin of salmon by fatty acid and $H R{ }^{13} \mathrm{C}$ NMR profiling. Food Chem 116:766-773

> McLoughlin MF, Graham DA (2007) Alphavirus infections in salmonids - a review. J Fish Dis 30:511-531

> Meier S, Mjøs SA, Joensen H, Grahl-Nielsen O (2006) Validation of a one-step extraction/methylation method for determination of fatty acids and cholesterol in marine tissues. J Chromatogr A 1104:291-298

Morton A, Volpe J (2002) A description of escaped farmed Atlantic salmon Salmo salar captures and their characteristics in one Pacific salmon fishery area in British Columbia, Canada, in 2000. Alaska Fish Res Bull 9: 102-110. Available at www.adfg.state.ak.us/pubs/afrb/ afrbabst.php

Olsen RE, Henderson RJ (1989) The rapid analysis of neutral and polar marine lipids using double-development HPTLC and scanning densitometry. J Exp Mar Biol Ecol 129:189-197

> Olsen RE, Skilbrei OT (2010) Feeding preference of recaptured Atlantic salmon Salmo salar following simulated escape from fish pens during autumn. Aquacult Environ Interact 1:167-174

Olsen RE, Henderson RJ, Ringø E (1991) Lipids of Arctic charr, Salvelinus alpinus (L.) I. Dietary induced changes in lipid class and fatty acid composition. Fish Physiol Biochem 9:151-164

Olsen RE, Henderson RJ, Suontama J, Hemre GI, Ringø E, Melle W, Tocher DR (2004) Atlantic salmon, Salmo salar, utilizes wax ester-rich oils from Calanus finmarchicus effectively. Aquaculture 240:433-449

> Olsen RE, Taranger GL, Svåsand T, Skilbrei OT (2013) Improved method for fatty acid profiling by various nonlethal and lethal sampling techniques in Atlantic salmon. Aquacult Environ Interact 4:251-261

Petursdottir H, Gislason A, Falk-Petersen S, Hop H, Svavarsson J (2008) Trophic interactions of the pelagic ecosystem over the Reykjanes Ridge as evaluated by fatty acid and stable isotope analyses. Deep-Sea Res II 55:83-93

> Robin JH, Regost C, Arzel J, Kaushik SJ (2003) Fatty acid profile of fish following a change in dietary fatty acid source: model of fatty acid composition with a dilution hypothesis. Aquaculture 225:283-293

Sægrov H, Hindar K, Kålås S, Lura H (1997) Escaped farmed 
Atlantic salmon replace the original salmon stock in the River Vosso, western Norway. ICES J Mar Sci 54: 1166-1172

Schröder V, de Leaniz CG (2011) Discrimination between farmed and free-living invasive salmonids in Chilean Patagonia using stable isotope analysis. Biol Invasions 13:203-213

Skaala O, Wennevik V, Glover KA (2006) Evidence of temporal genetic change in wild Atlantic salmon, Salmo salar L., populations affected by farm escapees. ICES J Mar Sci 63:1224-1233

Skaala O, Johnsen GH, Lo H, Borgstrøm R and others (2014) A conservation plan for Atlantic salmon (Salmo salar) and anadromous brown trout (Salmo trutta) in a region with intensive industrial use of aquatic habitats, the Hardangerfjord, western Norway. Mar Biol Res 10:308-322

Skilbrei OT (2010a) Reduced migratory performance of farmed Atlantic salmon post-smolts from a simulated escape during autumn. Aquacult Environ Interact 1: $117-125$

Skilbrei OT (2010b) Adult recaptures of farmed Atlantic salmon post-smolts allowed to escape during summer. Aquacult Environ Interact 1:147-153

Skilbrei OT (2012) The importance of escaped farmed rainbow trout (Oncorhynchus mykiss) as a vector for the salmon louse (Lepeophtheirus salmonis) depends on the hydrological conditions in the fjord. Hydrobiologia 686: 287-297

Skilbrei OT (2013) Migratory behaviour and ocean survival of escaped out-of-season salmon smolts. Aquacult Environ Interact 3:213-221

Skilbrei OT, Jørgensen T (2010) Recapture of cultured salmon following a large-scale escape experiment. Aquacult Environ Interact 1:107-115

Skilbrei OT, Wennevik V (2006) The use of catch statistics to

Editorial responsibility: Antonio Bode,

A Coruña, Spain monitor the abundance of escaped farmed salmon and rainbow trout in the sea. ICES J Mar Sci 63:1190-1200

Skilbrei OT, Holst JC, Asplin L, Mortensen S (2010) Horizontal movements of simulated escaped farmed Atlantic salmon (Salmo salar L.) in a western Norwegian fjord. ICES J Mar Sci 67:1206-1215

Skilbrei OT, Skulstad OF, Hansen T (2014) The production regime influences the migratory behaviour of escaped farmed Atlantic salmon. Aquaculture 424-425:146-150

Skilbrei OT, Heino M, Svåsand T (2015) Using simulated escape events to assess the annual numbers and destinies of escaped farmed Atlantic salmon of different life stages from farm sites in Norway. ICES J Mar Sci 72: 670-685

Solem $\varnothing$, Hedger RD, Urke HA, Kristensen T, Økland F, Ulvan EM, Uglem I (2013) Movements and dispersal of farmed Atlantic salmon following a simulated-escape event. Environ Biol Fish 96:927-939

Soto D, Jara F, Moreno C (2001) Escaped salmon in the inner seas, southern Chile: facing ecological and social conflicts. Ecol Appl 11:1750-1762

> Vollset KW, Skoglund H, Barlaup BT, Pulg U and others (2014) Can the river location within a fjord explain the density of Atlantic salmon and sea trout? Mar Biol Res 10: 268-278

Wasta Z, Mjøs SA (2013) A database of chromatographic properties and mass spectra of fatty acid methyl esters from omega-3 products. J Chromatogr A 1299:94-102

Weil C, Fefevre F, Bugeon J (2013) Characteristics and metabolism of different adipose tissues in fish. Rev Fish Biol Fish 23:157-173

Zhang Z, Glover KA, Wennevik V, Svåsand T and others (2013) Genetic analysis of Atlantic salmon captured in a netting station reveals multiple escapement events from commercial fish farms. Fish Manag Ecol 20:42-51

Submitted: October 6, 2014; Accepted: April 8, 2015 Proofs received from author(s): May 9, 2015 